\title{
LAW ENFORCEMENT ON UNDER AGE OF CRIMINAL WHICH ABUSE DRY MARIJUANA TYPES OF NARCOTICS
}

\author{
RR Lyia and Muhammad Agung Fazri
}

\author{
Departement of Law, IBLAM School of Law \\ Jalan Kramat Raya No.25, Jakarta Pusat
}

\begin{abstract}
Abstrack
The involvement of children in the world of narcotics cannot be separated from parental control, because parents must protect, educate and provide a decent life both physically and psychologically. Parents are expected to supervise and educate their children to stay away from narcotics abuse. By providing religious education and general education. The young generation is the backbone of the nation and the State, so that children, even though they have to face the law, must still receive protection. In writing this thesis the author provides an example of a case of a child who abuses narcotics and has been sentenced to imprisonment by a judge at the Pekanbaru High Court with his decision Number 68 / PID.SUS / 2013 / PTR. The formulation of the problems discussed by the author are: (1) How is law enforcement against offenders of minors who abuse narcotics? and (2) How is the application of material law to children as narcotics abusers as in Court Decision Number: 68 / PID.SUS / 2013 / PTR? The research method used by the author is a normative juridical method, which is to analyze the relationship between applicable laws and regulations with legal theories and the practice of implementing positive law concerning the issues discussed. Finally, the authors conclude that the application of material law to children as narcotics abusers as in Court Decision Number: 68 / PID.SUS / 2013 / PTR, turns out that there are differences in interpretation and differences in considerations so that there are differences in the provision of criminal sanctions against the accused. The District Court Judge sentenced a prison sentence of 1 (one) year, while the High Court judge imposed a heavier sanction of 2 (two) years and 6 (six) months imprisonment, which in the end had to be served, because this case only reached the appeal level in court High.
\end{abstract}

Keywords: Drugs, Narcotics abuse, Underage Child 


\title{
PENEGAKAN HUKUM TERHADAP PELAKU TINDAK PIDANA DI BAWAH UMUR YANG MENYALAHGUNAKAN NARKOTIKA JENIS GANJA KERING \\ (Studi Kasus Putusan Pengadilan Nomor :68/PID.SUS/2013/PTR.)
}

\author{
RR Lyia dan Muhammad Agung Fazri
}

\author{
Program Studi Sarjana Hukum, Sekolah Tinggi Ilmu Hukum IBLAM \\ Jalan Kramat Raya No. 25 Jakarta Pusat
}

\begin{abstract}
Intisari
Keterlibatan anak dalam dunia narkotika, tidak lepas dari kontrol orang tua, karena sebagaimana mestinya orang tua harus melindungi, mendidik dan memberikan kehidupan yang layak baik kebutuhan dari segi fisik maupun psikis. Orang tua diharapkan untuk mengawasi dan mendidik anaknya agar selalu menjauhi penyalahgunaan narkotika. Dengan memberikan pendidikan agama maupun pendidikan umum. Generasi muda adalah tulang punggung bangsa dan Negara, sehingga anak walaupun harus berhadapan dengan hukum harus tetap mendapatkan perlindungan. Dalam penulisan skripsi ini penulis memberikan contoh kasus seorang anak yang menyalahgunakan narkotika dan telah diputus dengan sanksi pidana penjara oleh hakim Pengadilan Tinggi Pekanbaru dengan Putusannya Nomor 68/PID.SUS/2013/PTR. Adapun rumusan masalah yang dibahas penulis adalah : (1) Bagaimana penegakan hukum terhadap pelaku tindak pidana anak di bawah umur yang menyalahgunakan narkotika? dan (2) Bagaimana penerapan hukum materiil terhadap anak sebagai penyalahguna narkotika sebagaimana dalam Putusan Pengadilan Nomor : 68/PID.SUS/2013/PTR ?. Metode penelitian yang digunakan penulis adalah metode yuridis normatif yaitu menganalisis kaitan antara peraturan perundang-undangan yang berlaku dengan teori-teori hukum dan praktek pelaksanaan hukum positif yang menyangkut permasalahan yang dibahas. Akhirnya penulis menyimpulkan bahwa Penerapan hukum materiil terhadap anak sebagai penyalahguna narkotika sebagaimana dalam Putusan Pengadilan Nomor : 68/PID.SUS/2013/PTR, ternyata ada perbedaan tafsir dan perbedaan pertimbangan sehingga terjadi perbedaan pemberian sanksi pidana terhadap terdakwa. Hakim Pengadilan Negeri menjatuhkan pidana penjara selama 1 (satu) tahun, sedangkan hakim Pengadilan Tinggi menjatuhkan sanksi lebih berat yaitu 2 (dua) tahun 6 (enam) bulan penjara., yang akhirnya harus dijalani, karena perkara ini hanya sampai di tingkat banding di pengadilan Tinggi.
\end{abstract}

Kata Kunci : Narkoba, Penyalahgunaan narkotika, anak di bawah umur 


\section{A. Pendahuluan}

Penyalahgunaan narkotika dan obatobatan terlarang di kalangan generasi muda atau anak-anak saat ini kian meningkat. Maraknya penyimpangan perilaku generasi muda tersebut dapat membahayakan keberlangsungan hidup bangsa ini di kemudian hari. Karena pemuda sebagai generasi yang diharapkan menjadi penerus bangsa, semakin hari semakin rapuh digerogoti zat-zat adiktif penghancur syaraf, Sehingga pemuda tersebut tidak dapat berpikir jernih. Penyalahgunaan narkotika disini, tidak hanya sebagai pengguna, pengedar, bahkan dapat juga sebagai penjual.

Keterlibatan anak dalam dunia narkotika, tidak lepas dari kontrol orang tua, karena sebagaimana mestinya orang tua harus melindungi, mendidik dan memberikan kehidupan yang layak baik kebutuhan dari segi fisik maupun psikis. Orang tua diharapkan untuk mengawasi dan mendidik anaknya agar selalu menjauhi penyalahgunaan narkotika. Dengan memberikan pendidikan agama maupun pendidikan umum. Generasi muda adalah tulang punggung bangsa dan negara. ${ }^{2}$ Pola asuh orang tua merupakan suatu keseluruhan interaksi antara orangtua dengan anak, di mana orang tua bermaksud menstimulasi anaknya dengan mengubah tingkah laku, pengetahuan serta nilai-nilai yang dianggap paling tepat oleh orang tua, agar anak dapat mandiri, tumbuh dan berkembang secara sehat dan optimal. Tipe pola asuh oleh orang tua memiliki

1 Atmasasmita, Romli, Tindak Pidana Narkotika Transnasional Dalam Sistem Hukum Pidana Indonesia, Bandung: PT. Citra Aditya Bakti. 2007, hlm. 9

2 Lisa, Juliana, dan Nengah Sutrisna, Narkoba, Psikotropika Dan Gangguan Jiwa, Yogyakarta: Nuha Medika. 2013, hlm. 62 peran yang besar dalam membentuk kepribadian anak kelak sampai mereka dewasa. Pola asuh tertentu akan mampu membentuk kepribadian anak yang matang, tangguh, percaya diri dan berpikir positif. Dikatakan bahwa kepribadian seperti ini akan dapat mencegah seseorang dari penyalahgunaan narkoba, kenakalan remaja.

Narkotika adalah zat atau obat yang berasal dari tanaman atau bukan tanaman, baik sintetis maupun semisintetis yang dapat menyebabkan penurunan atau perubahan kesadaran, hilangnya rasa nyeri, serta menimbulkan ketergantungan. Pada satu sisi, narkotika dan psikotropika merupakan obat atau bahan yang bermanfaat di bidang pengobatan, pelayanan kesehatan dan pengembangan ilmu pengetahuan. Jadi penyalahgunaan narkotika dapat dikatakan sebagai tindak pidana yang mempunyai konsekuensi hukum, dari segi hukum mengenai perbuatan penyalahgunaan narkotika dan ketentuan pidananya telah dilarang dalam peraturan perundang-undangan secara khusus, yaitu Undang-undang Nomor. 35 Tahun 2009 tentang Narkotika. ${ }^{3}$

Berkaitan dengan keterlibatan anak yang menyalahgunakan narkotika atau bahkan ikut terlibat dalam peredaran narkotika, umumnya mereka yang beresiko terjerumus dalam masalah narkotika adalah anak yang terlahir dari keluarga yang memiliki sejarah kekerasan dalam rumah tangga, dibesarkan dari keluarga yang broken home atau memiliki masalah perceraian, sedang stres atau depresi, memiliki pribadi yang tidak stabil atau mudah

3 Makaro, Taufik, Suhasril, dan Moh. Zakky, Tindak Pidana Narkotika, Jakarta: Ghalia Indonesia. 2005, hlm. 38 
terpengaruh, merasa tidak memiliki teman atau salah dalam pergaulan. ${ }^{4}$

Dalam penelitian ini penulis memberikan contoh kasus yang telah diputus oleh Pengadilan Tinggi Pekanbaru dengan Putusan Nomor : 68/PID.SUS/2013/PTR. Dalam kasus ini terdakwanya adalah HENGKY ADI SAPUTRA BIN HERMAN (17 tahun) yang oleh Jaksa Penuntut Umum didakwa secara tanpa hak atau melawan hukum, menawar untuk dijual, menjual, membeli, menjadi perantara dalam jual beli, menukar, menyerahkan atau menerima Narkotika Golongan I yaitu dalam bentuk tanaman berupa daun ganja kering (cannabinoid) bercampur tembakau seberat 1,7 gram., sehingga terdakwa diancam pidana pada pasal 114 ayat (1) Undang-Undang R.I No. 35 Tahun 2009 tentang Narkotika jo pasal 1 Undang-Undang R.I No. 11 Tahun 2012 tentang Sistem Peradilan Pidana Anak. Akhirnya berdasarkan bukti dan fakta persidangan maka hakim Pengadilan Negeri Tembilahan berdasarkan Putusan Nomor No:28/Pid.Sus.A/2013/ PN.Tbh. menetapkan bahwa terdakwa Terdakwa anak HENGKY ADI SAPUTRA BIN HERMAN, telah terbukti secara sah dan meyakinkan bersalah melakukan tindak pidana "Menyalahgunakan Narkotika Golongan I bagi diri sendiri"; dan menjatuhkan pidana terhadap terdakwa anak tersebut diatas dengan pidana penjara selama : 1 (satu) tahun. ${ }^{5}$ Namun atas putusan ini Jaksa Penuntut Umum mengajukan banding ke Pengadilan Tinggi Pekanbaru, yang akhirnya Pengadilan Tinggi Pekanbaru dengan Putusannya Nomor

68/PID.SUS/2013/PTR menetapkan

\footnotetext{
4 Soedjono, Narkotika Dan Remaja, Bandung: Alumni. 2003, hlm. 26

5 Cuplikan Putusan Pengadilan Negeri Tembilahan Nomor : 28/Pid.Sus.A/2013/PN.Tbh
}

bahwa terdakwa diputus bersalah melakukan tindak pidana "tanpa hak/melawan hukum membeli dan menjual narkotika golongan I" ; dan menjatuhkan pidana terhadap terdakwa tersebut dengan pidana penjara selama 2 (dua) tahun 6 (enam) bulan dan pidana denda sebesar Rp. 500.000.000,-(lima ratus juta rupiah) ; apabila denda termaksud tidak dapat dibayar, maka diganti dengan wajib latihan kerja selama 30 (tiga puluh) hari. ${ }^{6}$ Berdasarkan pertimbangan dan uraian di atas maka penulis menetapkan judul penelitian skripsi ini adalah : Penegakan Hukum Terhadap Pelaku Tindak Pidana Di Bawah Umur Yang Menyalahgunakan Narkotika Jenis Ganja Kering (Studi Kasus Putusan Pengadilan Nomor : 68/Pid.Sus/2013/Ptr.)

Adapun Rumusan masalah yang akan penulis bahas dalam tulisan ini adalah :

1. Bagaimana penegakan hukum terhadap pelaku tindak pidana anak di bawah umur yang menyalahgunakan narkotika?

2. Bagaimana penerapan hukum materiil terhadap anak sebagai penyalahguna narkotika sebagaimana dalam Putusan Pengadilan Nomor : 68/PID. SUS/2013/PTR ?

\section{B. Metode Penelitian}

Metode pendekatan yang dilakukan dalam penelitian hukum ini adalah dengan menggunakan metode pendekatan yuridis normatif. Penelitian hukum normatif merupakan penelitian yang mengutamakan data kepustakaan yaitu penelitian terhadap data sekunder. Data sekunder tersebut dapat berupa

6 Cuplikan Putusan PengadilanTinggi Pekanbaru Nomor : 68/PID.SUS/2013/PTR 
bahan hukum primer,sekunder maupun tersier. ${ }^{7}$ Penelitian ini meliputi penelitian mengenai ketentuan hukum positif yang berlaku di Indonesia yang berkaitan dengan anak sebagai pelaku tindak pidana.

Data sekunder tersebut dapat berupa bahan hukum primer, sekunder maupun tersier. ${ }^{8}$ Bahan hukum tersebut ini terdiri dari :

1. Bahan Hukum Primer

Bahan-bahan hukum yang digunakan dalam penelitian dengan kekuatan yang mengikat meliputi norma dan kaidah dasar seperti, peraturan perundang-undangan catatan-catatan resmi atau risalah dalam pembuatan perundangundangan, dan putusan hakim, dalam penelitian dan penulisan skripsi ini, meliputi : ${ }^{9}$ UndangUndang No. 35 tahun 2009 tentang narkotika, Undang-Undang Nomor 11 Tahun 2012 tentang Sietem Peradilan Pidana Anak, dan Peraturan-peraturan lainnya yang berkaitan dengan judul skripsi.

2. Bahan Hukum Sekunder

Bahan-bahan yang memberikan penjelasan mengenai bahan hukum primer dan implementasinya, seperti hasil-hasil penelitian, hasil karya dari kalangan hukum, makalah-makalah seminar, dan lain-lain. Dalam penelitian dan penulisan skripsi ini meliputi bahan-bahan bacaan yang ada hubungannya dengan penegakan hukum terhadap anak yang melakukan tindak pidana, sebagai

${ }^{7}$ Ronny Hanitijo, Metodologi Penelitian Hukum, Jakarta : Ghalia Indonesia, 2000, hlm.24

${ }^{8}$ Ronny Hanitijo, Metodologi Penelitian Hukum, Jakarta : Ghalia Indonesia, 1990, hlm.24

9 Mahmud Marzuki, Penelitian Hukum, Kencana, Jakarta, 2010, hlm. 141 objek yang teliti yaitu literatur dan karya ilmiah yang berkaitan dengan masalah yang akan di teliti.

3. Bahan Hukum Tersier

Bahan hukum yang memberikan penjelasan lebih lanjut dari bahan hukum primer dan sekunder yaitu, kamus, baik kamus terjemahan maupun kamus hukum, majalah dan internet (virtual research). ${ }^{10}$

\section{Hasil Penelitian dan Pembahasan}

\section{Penegakan Hukum Terhadap Anak Sebagai Penyalahguna Narkotika}

Pentingnya pengawasan terhadap peredaran narkotika secara ketat karena saat ini pemanfaatannya banyak untuk hal-hal yang negatif.

Serta melalui perkembangan teknologi informasi dan komunikasi, penyebaran narkotika sudah menjangkau hampir ke semua wilayah Indonesia hingga ke pelosok-pelosok. Daerah yang sebelumnya tidak pernah tersentuh oleh peredaran narkotika, lambat laun berubah menjadi sentral peredaran narkotika. Begitu pula anak-anak yang pada mulanya awam terhadap barang haram ini, telah berubah menjadi sosok pecandu yang sukar untuk dilepaskan ketergantungannya. ${ }^{11}$

Pengguna narkotika sangat beragam dan menjangkau semua lapisan masyarakat, mulai dari anak-anak hingga orang dewasa, orang awam hingga artis, bahkan hingga pejabat publik.

Efek negatif yang ditimbulkan akibat pengguna narkotika secara berlebihan dalam jangka waktu lama serta tidak

10 Soekanto Soerjono dan Sri Mamudji, Penelitian Hukum Normatif Suatu Tinjauan Singkat, PT RajaGrafindo Persada, 1995, hlm. 62 11 Hamzah, Andi, dan Surachman, Kejahatan Narkotika Dan Psikotropika, Op. Cit., hlm. 82 
diawasi oleh ahlinya, dapat menimbulkan berbagai dampak negatif pada penggunanya, baik secara fisik maupun psikis. Tidak jarang pengguna narkotika dapat memicu terjadinya berbagai tindak pidana. Dalam hukum pidana Indonesia, tindak pidana narkotika merupakan salah satu perbuatan melawan hukum yang bersifat khusus. Pengaturan terhadap tindak pidana narkotika ini dituangkan ke dalam Undang-Undang Nomor 35 Tahun 2009 Tentang Narkotika. ${ }^{12}$

Tindak pidana narkotika tidak lagi dilakukan secara perseorangan, melainkan melibatkan banyak orang yang secara bersama-sama, bahkan merupakan satu sindikat yang terorganisasi dengan jaringan yang luas yang bekerja secara rapi dan sangat rahasia. ${ }^{13}$ Kejahatan dibidang narkoba tidak seluruhnya dilakukan oleh orang dewasa, tetapi ada kalanya kejahatan ini dilakukan pula bersama-sama dengan anak di bawah umur (belum genap 18 tahun usianya). Sebagai contoh studi kasus kronologi penangkapan terdakwa atas nama HENGKI yang melakukan transaksi jual beli narkotika jenis ganja kering kepada beberapa terdakwa lainnya, pada waktu terdakwa melaksanakan transaksi hingga saat penangkapan terdakwa HENGKI berusia belum berumur 18 tahun, dengan dibuktikan oleh akta kelahiran terdakwa. Anak-anak yang belum dewasa cenderung mudah dipengaruhi untuk melakukan perbuatan yang berhubungan dengan narkotika, karena jiwanya belum stabil diakibatkan perkembangan fisik dan psikis. Perbuatan memanfaatkan

12 Lisa, Juliana, dan Nengah Sutrisna, Narkoba, Psikotropika Dan Gangguan Jiwa, Op. Cit., hlm. 82

13 Soedjono Dirjosisworo, Hukum Narkotika Indonesia, Bandung, Citra Aditya Bhakti, 2005, hlm 3 anak di bawah umur untuk melakukan kegiatan narkotika merupakan tindak pidana yang diatur dalam Pasal 133 Undang-Undang nomor 35 tahun 2009 tentang Narkotika yang menjelaskan sebagai berikut :

"Setiap orang yang menyuruh, memberi atau menjanjikan sesuatu, memberikan kesempatan, menganjurkan, memberikan kemudahan, memaksa dengan ancaman, memaksa dengan kekerasan, melakukan tipu muslihat, atau membujuk anak yang belum cukup umur untuk melakukan tindak pidana sebagaimana dimaksud dalam Pasal 111, Pasal 112, Pasal 113, Pasal 114, Pasal 115, Pasal 116, Pasal 117, Pasal 118, Pasal 119, Pasal 120, Pasal 121, Pasal 122, Pasal 123, Pasal 124, Pasal 125, Pasal 126, dan Pasal 129 dipidana dengan pidana mati atau pidana penjara seumur hidup, atau pidana penjara paling singkat 5 (lima) tahun dan paling lama 20 (dua puluh) tahun dan pidana denda paling sedikit Rp. 2.000.000.000,00 (dua miliar rupiah) dan paling banyak Rp. 20.000.000.000,00 (dua puluh miliar rupiah)". ${ }^{14}$

Ketentuan dari Pasal tersebut di atas, hanya dikenakan terhadap orang yang memanfaatkan anak yang belum dewasa saja, sedangkan anak yang bersangkutan tetap dapat dipidana berdasarkan ketentuan undang-undang narkotika sesuai dengan perbuatannya. Namun, dikarenakan anak di bawah umur maka berlakulah ketentuan undang-undang peradilan anak sehingga berkasnya harus dipisah.

Apabila terjadi kasus yang melibatkan anak dalam penyalahgunaan narkoba, maka anak tersebut merupakan anak yang berhadapan dengan hukum

14 Pasal 133 Undang-Undang nomor 35 tahun 2009 tentang Narkotika 
dan ketentuan hukum yang dipergunakan adalah undang-undang peradilan anak. Undang-undang tersebut tidak hanya mengatur ketentuan pidana formil, namun juga mengatur ketentuan pidana materiil terhadap anak yang terlibat dalam masalah hukum, khususnya dalam hukum pidana. Sedangkan anak yang bersangkutan tetap dapat dipidana berdasarkan undang-undang narkotika sesuai dengan perbuatannya. Berhubung anak di bawah umur berlaku UndangUndang Peradilan Anak, maka berkasnya harus terpisah, kecuali pelaku pelanggaran adalah anak yang belum dewasa juga, berkas perkaranya dapat dijadikan satu, hanya peran perbuatannya yang berbeda. ${ }^{15}$

Seseorang yang melakukan penyalahgunaan narkotika selain dianggap telah melakukan tindakan kriminal, ia juga merupakan korban dari perbuatannya sendiri. Selama ini, aparat penegak hukum cenderung menjatuhkan sanksi pidana bagi para pelaku tindak pidana tersebut, tanpa melakukan rehabilitasi. Dengan memberikan sanksi pidana berupa penjara, diharapkan para pelaku tindak pidana penyalahgunaan narkotika menjadi jera dan tidak mengulangi perbuatannya. Namun yang terjadi adalah sebaliknya, sanksi pidana berupa penjara tersebut tidak efektif untuk membuat mereka jera memakai narkotika. ${ }^{16}$ seperti pada tuntutan jaksa penuntut umum Tuntutan Pidana tanggal 21 Februari 2013 Nomor :REG.PERK : Nomor : PDM-10/TMBL/01/2013 Terdakwa telah dituntut sebagai berikut :

1. Menyatakan terdakwa HENGKY ADI SAPUTRA BIN HERMAN

15 Gatot Supramono, Hukum Narkotika Indonesia, Jakarta, Djambatan, 2004, hlm 204

${ }^{16}$ Dani Krisnawati, dkk., Bunga Rampai Hukum Pidana Khusus, Jakarta, Pena Pundi Aksara, 2006, hlm 93 telah terbukti secara sah dan meyakinkan bersalah melakukan tindak pidana "membeli dan menjual narkotika golongan I berupa daun ganja kering" sebagaimana diatur dan diancam pidana pada pasal 114 ayat (1) UU RI No. 35 Tahun 2009 tentang Narkotika jo Pasal 1 UU RI No.3 Tahun 1997 tentang Peradilan Anak sesuai dengan dakwaan primair kami tertanggal 30 Januari 2013 ;

2. Menjatuhkan pidana terhadap terdakwa HENGKY ADI SAPUTRA BIN HERMAN berupa pidana penjara selama 5 (lima) tahun dan denda sejumlah Rp 1.000.000.000,- subsidair 6 (enam) bulan penjara, dikurangi selama terdakwa ditahan dengan perintah terdakwa tetap ditahan ;

3. Menetapkan barang bukti.

Sesuai dengan penjelasan singkat studi kasus di atas penulis berpendapat tuntutan Jaksa penuntut umum lebih menekankan sanksi hukuman penjara Tanpa proses detoksifikasi melalui proses rehabilitasi medis, mereka akan segera kembali mencari narkotika begitu keluar dari lembaga pemasyarakatan.

Dalam perspektif Undang-Undang nomor 35 Tahun 2009 tentang Narkotika, tidak diatur secara khusus mengenai anak sebagai pelaku tindak pidana penyalahgunaan narkotika. Di dalam undang-undang ini juga, diberikan alternatif lain dalam penyelesaian kasus anak pelaku tindak pidana penyalahguna narkotika yaitu secara diversi, sehingga tidak melibatkan anak ke dalam proses peradilan yang panjang dan cukup rumit bagi anak yang masih di bawah umur. Landasan hukum terhadap 
pemberlakukan Diversi anak yang berhadapan dengan hukum termuat dalam ketentuan Pasal Undang-Undang Narkotika. ${ }^{17}$

\section{Penerapan Diversi Terhadap Anak Yang Menyalahgunakan Narkotika}

Perkembangan pengaturan narkotika di Indonesia tidak terlepas dari akibat hukum dari berbagai Konvensi Internasional tentang narkotika yang diratifikasi oleh Indonesia yaitu Convention on Psychotrophic Substances 1971 (Konvensi Psikotropika 1971) dan United Nation Convention Against Illicit Traffic in Narotic Drugs and Psychotropic Substances, 1988 (Konvensi Perserikatan Bangsa-Bangsa Tentang Peredaran Gelap Narkotika dan Psikotropika, 1988).

Kedua konvensi tersebut telah menjadi hukum nasional Indonesia lewat cara aksesi yang kemudian diratifikasi melalui Undang-Undang diratifikasi melalui Undang-Undang Nomor 8 Tahun 1996 tentang Pengesahan Convention on Psychotropic Substances 1971 (Konvensi Psikotropika 1971). Sedangkan diratifikasi Convention Against Illicit Traffic in Narotic Drugs and Psychotropic Substances, 1988 melalui Undang-Undang Nomor 07 Tahun 1997.

Pada dasarnya kebijakan hukum pidana dalam penanggulangan narkoba di Indonesia sudah sejak lama dilakukan. Diawali dengan berlakunya Ordonansi Obat Bius (Verdoovende Middelen Ordonnantie, Stbl.1927No.278 jo. No.536). Ordonansi ini kemudian diganti dengan UU No. 9 Tahun 1976 tentang Narkotika. Selanjutnya undang-undang ini diganti menjadi UU No. 22 Tahun 1997 tentang Narkotika sampai dengan munculnya UU No. 35 Tahun 2009

17 Gatot Supramono, Hukum Narkotika Indonesia, Jakarta, Op. Cit., hlm. 205 sebagai pembaharuan terbaru dari undang-undang tentang Narkotika. ${ }^{18}$

Penggunaan hukum pidana sebagai sarana penanggulangan penyalahgunaan narkotika yang dilakukan oleh anak hakikatnya merupakan pilihan yang bersifat dilematis. Mengingat peradilan pidana sebagai sarana penanggulangan penyalahgunaan narkotika yang dilakukan oleh anak seringkali menampilkan dirinya hanya sebagai "mesin" hukum yang hanya akan menghasilkan "keadilan prosedural" (procedural justice). Sehingga hasilnya seringkali tidak memuaskan dan jelasjelas mengabaikan kepentingan dan kesejahteraan anak. Sehingga hasilnya seringkali tidak memuaskan dan jelasjelas mengabaikan kepentingan dan kesejahteraan anak. $^{19}$

Perlindungan anak sebagai usaha untuk melindungi anak agar anak dapat melaksanakan hak dan kewajibannya secara seimbang dan manusiawi. Perwujudan berupa pembinaan, pembimbingan, pendampingan, penyertaan, pengawasan pencegahan, pengaturan penjaminan yang edukatif yang mendidik aspek-aspek kontruktif, integratif fisik dan sosial anak. Anak adalah mereka yang belum dewasa dan menjadi dewasa karena peraturan tertentu (mental, fisik dan sosial belum dewasa). ${ }^{20}$

Sebagai upaya untuk memberikan perlindungan terhadap anak dalam proses peradilan, agar kepentingan dan kesejahteraan anak tetap diperhatikan dan dapat diwujudkan, Sudarto memberikan komentar berkaitan dengan

\footnotetext{
${ }^{18}$ Ibid., hlm. 10

${ }^{19}$ Ibid.

20 Arif Gosita, Permasalahan Perlindungan Anak, Jakarta, Akademika Presindo, 2009, hlm. 2
} 
hal tersebut yang mana mengatakan bahwa :

"Segala aktivitas yang dilakukan dalam rangka peradilan anak ini, apakah itu dilakukan oleh polisi, jaksa ataukah pejabat-pejabat lainnya, harus didasarkan pada suatu prinsip: demi kesejahteraan anak, demi kepentingan anak. jadi apakah hakim akan menjatuhkan pidana ataukah tindakan harus didasarkan pada kriterium apa yang paling baik untuk kesejahteraan anak yang bersangkutan, tentunya tanpa mengurangi perhatian kepada kepentingan masyarakat". ${ }^{21}$

Bahwa menurut analisa hakim pengadilan negri terdakwa anak HENGKY ADI SAPUTRA BIN HERMAN ;

1. Tidak terbukti secara sah dan meyakinkan bersalah melakukan tindak pidana sebagaimana yang termuat dalam dakwaan primair yang didakwakan oleh Jaksa Penuntut Umum,

2. Membebaskan terdakwa anak dari dakwaan primair yang didakwakan oleh Jaksa Penuntut Umum.

3. Menyatakan Terdakwa anak telah terbukti secara sah dan meyakinkan bersalah melakukan tindak pidana "Menyalahgunakan Narkotika Golongan I bagi diri sendiri".

4. Menjatuhkan pidana terhadap terdakwa anak tersebut diatas dengan pidana penjara selama : 1 (satu) tahun.

Berdasarkan hal tersebut penulis berpendapat kepentingan anak dan kesejahteraan anak tidak boleh dikorbankan demi kepentingan masyarakat, ataupun kepentingan nasional, mengingat hal itu tidak lain justru akan dapat menimbulkan bentuk

${ }^{21}$ Sudarto, Hukum dan Hukum Pidana, Bandung, Bandung, Alumni, hlm 140 kejahatan lain atau korban lain, upaya untuk mengalihkan penanganan anak dari jalur yustisial menuju jalur nonyustisial (diversi) menjadi sangat urgen.

Melalui upaya diversi terhadap perilaku anak yang menyimpang atau melakukan kejahatan kiranya dapat dilakukan penyelesaian yang lebih baik, tanpa mengabaikan kepentingan dan kesejahteraan anak, serta dapat dilakukan tindakan yang tepat sesuai dengan kebutuhan dan kepentingan anak. Kebijakan pengalihan atau diversi ini merupakan penyelesaian yang terbaik yang dapat dijadikan formula dalam penyelesaian beberapa kasus yang melibatkan anak sebagai pelaku tindak pidana, khususnya dalam penanganan anak penyalahguna narkotika. Sehingga akan lebih tepat dalam menentukan tindakan-tindakan (treatment) yang perlu diterapkan terhadapnya.

Seperti yang ditegaskan oleh Larry J.Siegel, yang menyatakan sebagai berikut : ${ }^{22}$

"Kebanyakan program diversi/pengalihan dilaksanakan dengan mempergunakan suatu formula khusus untuk memilih remaja yang dilkutsertakan dalam program pengalihan. Kriteria seperti pelaku baru, pelaku non kekerasan, atau seorang berstatus offender, atau pecandu minuman beralkohol dipergunakan untuk memilih klien. Pada program-program tertentu, sang remaja akan diminta untuk secara suka rela berpartisipasi dalam pelayanan masyarakat,sebagai contoh ikut membantu pada dinas sosial dan tim penyelamatan sebagai ganti kehadiran di pengadilan. Setelah mengikuti program tersebut, jaksa diharapkan akan sepakat untuk menolak dan menutup suatu kasus setelah seorang remaja menyelesaikan

\footnotetext{
${ }^{22}$ Ibid, hlm 322-323
} 
suatu program pemulihan (treatmen program). Akhirnya, beberapa program dapat dilaksanakan oleh hakim peradilan anak setelah hearing awal."

Diversi merupakan langkah kebijakan non-penal penanganan anak pelaku kejahatan, karena penanganannya dialihkan di luar jalur sistem peradilan anak, melalui cara-cara pembinaan jangka pendek atau cara-cara lain yang bersifat pembinaan. Diversi berangkat dari asumsi bahwa proses penanganan anak lewat sistem peradilan anak lebih besar kemungkinan negatifnya daripada positifnya bagi perkembangan anak.

Berkaitan dengan penanganan anak penyalahguna narkotika, permasalahan pokok yang ditimbulkan dari proses peradilan pidana anak atau suatu putusan pidana adalah Stigma yang melekat pada terpidana penyalahgunaan narkotika setelah selesai proses peradilan pidana. Kecenderungan meningkatnya penyalahgunaan narkotika yang dilakukan anak atau pelaku pada usia muda, mendorong upaya penanggulangan dan penanganannya secara khusus dalam bidang hukum pidana anak baik secara formil maupun materiil. Dalam perspektif kebijakan pidana penanggulangan kejahatan hakikatnya merupakan suatu usaha yang rasional dan masyarkat dalam menanggulangi kejahatan. ${ }^{23}$

Sebagai usaha yang rasional di masyarakat, penanggulangan kejahatan termasuk penanggulangan penyalahgunaan narkotika, harus bertolak dan diagnosa yang tepat. Pada pokoknya anak yang menyalahgunakan narkotika tidak dapat dilihat semata-mata sebágai pelaku tindak pidana, tetapi juga harus dilihat sebagai korban. Pendekatan

${ }^{23}$ Sudarto, Hukum dan Hukum Pidana, Op. Cit, hlm 38 paradigmatik ini pada hakikatnya bertolak dan pemikiran bahwa (kejahatan) penyalahgunaan narkotika dapat dikualifikasi sebagai crime with without victim. Dengan demikian, korban kejahatan penyalahgunaan narkotika adalah pelaku itu sendiri, bukan orang lain. Oleh karenanya, tidak pada tempatnya apabila dalam hal terjadi penyalahgunaan narkotika yang bersangkutan hanya dilihat sebagai pelaku dan tidak dilihat sebagai korban. Penegasan terhadap persoalan ini dipandang sangat urgen berkitan dengan upaya yang harus ditempuh dalam penanggulangannya.

Perlu digaris bawahi, bahwa perlakuan terhadap pelaku tindak pidana dengan perlakuan terhadap korban adalah tidak sama. Dengan demikian, memahami posisi anak yang terlibat dalam tindak pidana merupakan ukuran untuk melihat sejauhmana tingkat akurasi perlakuan yang diberikan kepadanya. Dengan kata lain, penegasan terhadap persoalan ini penting untuk menentukan obat yang harus diberikan. Apakah ia harus dipidana, oleh karena ia hanya dipandang sebagai pelaku ataukah justru ia harus mendapatkan rehabilitasi karena ia dipandang sebagai korban. Dengan ketepatan diagnosa, maka obat yang harus diberikan kepadanya juga akan tepat dan efektif. ${ }^{24}$

Bertolak dan pemikiran yang demikian, menurut penulis penanggulangan terhadap penyalahgunaan narkotika yang dilakukan oleh anak dengan menggunakan sarana hukum pidana dirasa tidak pada tempatnya. Pandangan tersebut berangkat dari beberapa alasan sebagai berikut: Pertama, sebagai sarana

Hukum Narkotika Indonesia, Op. Cit., hlm. 114 
penanggulangan kejahatan hukum pidana pada dasarnya merupakan obat yang hanya diorientasikan pada penanggulangan setelah terjadinya kejahatan. Jadi, penggunaan hukum pidana sebagai sarana penanggulangan kejahatan hanya bersifat korektif dan bersifat represif. Pendekatan yang demikian dapat ditoleransi manakala hanya diorientasikan pada pelaku tindak pidana. Padahal, anak yang melakukan penyalahgunaan narkotika tidak hanya sematamata sebagai pelaku tindak pidana, tetapi juga sebagai korban. ${ }^{25}$

Kedua, bertolak dari pemikiran, bahwa anak yang menyalahgunakan narkotika adalah juga korban, maka upaya untuk memberikan perlindungan terhadap anak yang menyalahgunakan narkotika juga menjadi prioritas. Penanganan anak korban penyalahgunaan narkotika dapat digunakan upaya alternatif penghukuman dengan prinsip restoratif. Prinsip ini memposisikan proses pemidanaan terhadap anak sebagai "The Last Resort" bukan "The First Resort".

Dalam teori hukum pidana disebut juga sebagai Ultimum Remedium. Hal ini bertujuan agar anak dapat memperbaiki dirinya sesuai dengan kehendak dan kepentingan bagi si anak (The Best Interest of the Child) ketika dirinya 1680 berhadapan dengan hukum. Meskipun pemidanaan merupakan alat yang ampuh yang dimiliki Negara guna memerangi kejahatan namun pemidanaan bukanlah merupakan alat satu-satunya guna memperbaiki keadaan, harus ada kombinasi antara upaya represif dan preventif dalam penanganan anak penyalahguna narkotika yaitu melalui

\footnotetext{
${ }^{25}$ Ibid., hlm. 115
}

Diversi dengan cara rehabilitasi medis maupun rehabilitasi sosial. ${ }^{26}$

Pertimbangan dilakukan diversi yaitu filosofi sistem peradilan pidana anak untuk melindungi dan merehabilitasi (protection and rehabilitation) anak pelaku tindak pidana. Tindakan diversi juga dilakukan sebagai upaya pencegahan seorang pelaku anak menjadi pelaku kriminal dewasa. Usaha pencegahan anak inilah yang membawa aparat penegak hukum untuk mengambil wewenang diskresi yang sering disebut juga dengan istilah deinstitutionalisation dari sistem peradilanpidana formal. ${ }^{27}$

PENERAPAN

HUKUM PIDANA MATERIIL TERHADAP ANAK SEBAGAI PENYALAHGUNA NARKOTIKA SEPERTI DALAM PUTUSAN PENGADILAN NOMOR 68/PID.SUS/2013/PTR

\section{Pemberian Perlindungan Hukum Terhadap Anak Yang Menyalahgunakan Narkotika}

Dalam Pasal 2 Undang-Undang Nomor 11 Tahun 2012 tentang Sistem Peradilan Pidana Anak, terdapat asas-asas yang perlu diperhatikan dalam hal perlindungan hukum terhadap anak yang berkonflik dengan hukum, antara lain: ${ }^{28}$

1. Perlindungan

2. Keadilan

3. Nondiskriminasi

4. Kepentingan yang terbaik bagi anak

5. Penghargaan terhadap pendapat anak

6. Kelangsungan hidup dan tumbuh kembang

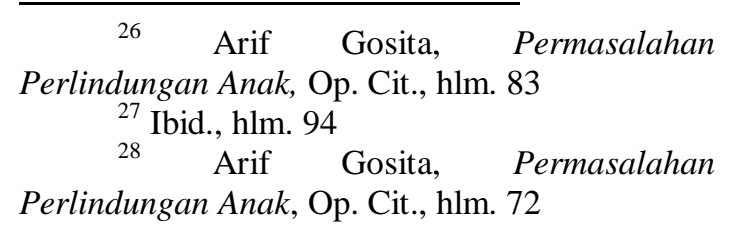


7. Pembinaan dan pembimbingan Anak

8. Proporsional

9. Perampasan kemerdekaan dan pemidanaan sebagai upaya terakhir

10. Penghindaran pembalasan

Jika dilihat dari penjatuhan sanksi dari Putusan Nomor 68/PID.SUS/2013/PTR, memang sudah tepat dan sesuai jika dilihat dari Pasal 69 ayat (1) Undang-Undang Nomor 11 tahun 2012 tentang Sistem Peradilan Pidana Anak UU yang mengizinkan penjatuhan sanksi pidana hanya kepada anak yang telah berumur 17 tahun, tetapi hal ini jelas bertentangan dengan pasal 64 ayat (2) huruf e Undang-Undang RI Nomor 35 tahun 2014 tentang Perubahan Atas Undang-Undang Nomor 35 Tahun 2014 Tentang Perlindungan Anak yaitu Perlindungan khusus bagi anak yang berhadapan dengan hukum dilaksanakan melalui pembebasan dari penyiksaan, penghukuman, atau perlakuan lain yang kejam, tidak manusiawi serta merendahkan martabat dan derajatnya, serta pasal 64 ayat (2) huruf g yaitu penghindaran dari penangkapan, penahanan atau penjara, kecuali sebagai upaya terakhir dan dalam waktu yang paling singkat. Hukuman penjara 2 tahun 6 bulan merupakan waktu yang cukup lama dan sangat berat untuk dijalani oleh anak, dan akan berimbas pada pertumbuhan dan perkembangan di usianya. ${ }^{29}$ Di dalam Undang -Undang Sistem Peradilan Pidana Anak dikenal istilah diversi, yang merupakan pengalihan dari proses penyelesaian perkara di peradilan ke proses penyelesaian di luar pengadilan.

Meninjau pada pasal 9 ayat (2) UU Sistem Peradilan Pidana Anak, disebutkan

${ }^{29}$ Maidin Gultom, Perlindungan Hukum Terhadap Anak, Bandung, Refika Aditama, 2008, hlm.120. bahwa pelaksanaan diversi dalam peradilan pidana anak harus selalu diupayakan, melihat hal tersebut penulis berpendapat bahwa diversi tetap dapat diterapkan pada tindak pidana tanpa korban, dimana tindak pidana narkotika merupakan kejahatan tanpa korban (crime without victim), maka anak sebagai pelaku disini, juga sekaligus menjadi korban. Terkait hal ini pun menurut penulis diversi hanya dapat dilakukan oleh penyidik bersama pelaku dan/atau keluarganya, pebimbing kemasyarakatan, serta dapat melibatkan tokoh masyarakat untuk bersama-sama mencari penyelesaian yang adil dengan menekankan pemulihan kembali pada keadaan semula dan bukan pembalasan atau yang lebih dikenal dengan istilah pendekatan restorative justice (keadilan restoratif).

Kesepakatan diversi yang tercantum dalam pasal 11 UU SPPA (sistem peradilan pidana anak) dapat berbentuk penyerahan kembali kepada orang tua/wali, rehabilitasi medis dan psikososial, serta mengikuti pendidikan atau pelatihan di lembaga pendidikan atau LPKS (Lembaga Penyelenggaraan Kesejahteraan Sosial) paling lama 3 (tiga) bulan.

Penyelesaian di luar proses peradilan tersebut diharapkan mampu memberikan rasa keadilan terhadap anak yang berhadapan dengan hukum dan dengan mengutamakan perlindungan kepada anak. ${ }^{30}$

\section{Tinjauan Umum Pemidanaan Terhadap Putusan Pengadilan Nomor 68/PID.SUS/2013/PTR \\ 1. Posisi perkara berdasarkan Dakwaan jaksa Penuntut Umum $^{31}$}

a. Dari sisi Primairnya :

Berdasarkan keterangan kronologi pada saat pembuatan Berita acara penangkapan, terdakwa HENGKY ADI SAPUTRA Bin HERMAN menemui HAYUYUN (masih dalam pencarian

\footnotetext{
${ }^{30}$ Ibid., hlm. 123

31 Cuplikan Putusan Pengadilan Tinggi Pekanbaru Nomor 68/PID.SUS/2013/PTR
} 
oleh polisi) dirumahnya didaerah Telaga Bone Desa Sungai Piring Kecamatan Batang Tuaka Kabupaten Inhil untuk membeli daun ganja kering, dan untuk transaksi jual beli daun ganja kering tersebut disepakati dilakukan pada hari Minggu tanggal 23 Desember 2012 sekira pukul 19.00 Wib bertempat dipinggir sungai sekitar pasar baru Sungai Piring Kecamatan Batang Tuaka Kabupaten Inhil sebanyak dua paket seharga Rp. 40.000.-.

Kemudian pada hari Kamis tanggal 27 Desember 2012 sekira pukul 16.00 Wib sewaktu terdakwa lagi menjaga warung didepan rumah, tiba-tiba datang FAHRUDIN Bin DANI bersama AHARUL FIKRI Alias IPONG dan M. AMIN Alias JULING (DPO), M. AMIN Alias JULING bertanya kepada terdakwa "ada lagi barang ? (daun ganja kering)" lalu terdakwa jawab "ada" selanjutnya M. AMIN Alias JULING berkata "berapa harganya?" dan terdakwa jawab "Rp.20.000.-" kemudian M. AMIN Alias JULING berkata "beli satu" lalu terdakwa jawab "ya lah". Setelah itu terdakwa pergi mengambil daun ganja kering yang disimpan dibagian belakang rumah dibawah kolong dapur sebanyak satu paket. terdakwa melihat FAHRUDIN Bin DANI, AHARUL FIKRI Alias IPONG dan M. AMIN Alias JULING sedang patungan mengumpulkan uang yaitu FAHRUDIN Bin DANI mengeluarkan uang pecahan Rp. 10.000.- sedangkan AHARUL FIKRI Alias IPONG dan M. AMIN Alias JULING masing-masing mengeluarkan uang pecahan Rp. 5000.- setelah uang tersebut terkumpul lalu FAHRUDIN Bin DANI serahkan kepada terdakwa dan terdakwa pun menyerahkan satu paket daun ganja kering kepada FAHRUDIN Bin DANI, selanjutnya FAHRUDIN Bin DANI, AHARUL FIKRI Alias IPONG dan M. AMIN Alias JULING pergi meninggalkan terdakwa.

Setelah itu terdakwa pergi bermain gasing didaerah Nipah Kuning jalan lintas Teluk Pinang Desa Gemilang Kecamatan Batang Tuaka dan disekira pukul 17.30 Wib saat terdakwa hendak pulang terdakwa telah ditangkap oleh anggota polisi, karena telah membeli untuk dijual kembali daun ganja kering tanpa izin dari pihak yang berwenang kepada FAHRUDIN Bin DANI yang telah ditangkap sebelumnya dan temukan daun ganja kering bercampur tembakau sebanyak 1,7 gram. Kemudian daun ganja kering bercampur tembakau tersebut dilakukan pengujian di Lab. Forensik Polri Cab. Medan No.Lab : 82/NNF/2013 tanggal 10 Januari 2013 dengan kesimpulan : Barang Bukti An. Tersangka FAHRUDIN Bin DANI dan HENGKY ADI SAPUTRA Bin HERMAN adalah benar mengandung cannabinoid (ganja) dan terdaftar dalam golongan 1 nomor urut 8 lampiran UU R.I No. 35 Tahun 2009 tentang Narkotika.

Bahwa terdakwa pada saat ditangkap belum berusia 18 tahun yaitu kurang satu hari sebagaimana dalam akta lahir an. terdakwa No II/8.690/2007 tanggal 01 Agustus 2007.

b. Dari sisi Subsidarirnya :

Terdakwa

HENGKY ADI SAPUTRA Bin HERMAN pada hari Kamis tanggal 27 Desember 2012 sekira pukul $17.30 \mathrm{Wib}$ atau pada suatu waktu lain dalam bulan Desember Tahun 2012 bertempat jalan Lintas Teluk Pinang Desa Gemilang Kecamatan Batang Tuaka Kabupaten Inhil atau pada tempat lain yang masih dalam daerah Hukum Pengadilan Negeri Tembilahan yang berwenang memeriksa dan mengadili perkara ini, setiap penyalah guna Narkotika golongan I berupa ganja 
(cannabinoid) bagi diri sendiri, Perbuatan tersebut dilakukan terdakwa dengan cara sebagai berikut :

- Sebelumnya terdakwa HENGKY
ADI SAPUTRA Bin HERMAN menemui HAYUYUN (masih dalam pencarian oleh polisi)dirumahnya didaerah Telaga Bone Desa Sungai Piring Kecamatan Batang Tuaka Kabupaten Inhil untuk membeli daun ganja kering dan untuk transaksi jual beli daun ganja kering tersebut disepakati dilakukan pada hari Minggu tanggal 23 Desember 2012 sekira pukul $17.00 \mathrm{Wib}$ bertempat dipinggir sungai sekitar pasar baru Sungai Piring Kecamatan Batang Tuaka Kabupaten Inhil seharga Rp. 20.000.-, kemudian pada hari Rabu tanggal 26 Desember 2012 sekira pukul 17.00 Wib bertempat disamping tiang gawang lapangan bola Kampung Baru Desa Gemilang Kecamatan Batang Tuaka terdakwa menggunakan daun ganja kering tersebut untuk dirinya dengan cara terlebih dulu terdawa mencampurkan daun ganja dengan tembakau lalu campuaran tersebut terdakwa linting/gulung dengan menggunakan kertas paper menjadi dua lingting rokok setelah itu salah satu ujung lintingan tersebut terdakwa bakar dengan korek api sedangkan salah satu ujung lintingan lainya terdakwa hisap seperti menghisap rokok.

- Setelah terdakwa menggunakan daun ganja kering seperti tersebut diatas terdakwa merasa lapar dan membuat nafsu makan terdakwa menjadi meningkat, kemudian pada pada hari Kamis tanggal 28 Desember 2012 sekira pukul 17.30 Wib bertempat didaerah Nipah Kuning jalan lintas Teluk Pinang Desa Gemilang Kecamatan Batang Tuaka saat terdakwa hendak pulang dari bermain, terdakwa telah ditangkap oleh anggota polisi karena telah menyalahgunakan daun ganja kering untuk dirinya tanpa izin dari pihak yang berwenang setelah itu urine terdakwa dilakukan pengujian di Lab. Forensik Polri Cab. Medan No.Lab : 81/NNF/2013 tanggal 10 Januari 2013 dengan kesimpulan : Barang Bukti Urine An. Tersangka HENGKY ADI SAPUTRA Bin HERMAN adalah benar mengandung cannabinoid (ganja) dan terdaftar dalam golongan 1 nomor urut 8 lampiran UU R.I No. 35 Tahun 2009 tentang Narkotika.

Bahwa terdakwa pada saat ditangkap belum berusia 18 tahun yaitu kurang satu hari sebagaimana dalam akta lahir an. terdakwa No II/8.690/2007 tanggal 01 Agustus 2007.

\section{Berdasarkan Tuntutan Jaksa Penuntut Umum, Jaksa Penuntut Umum}

Mengajukan Tuntutan ;

a. Primair : Perbuatan terdakwa sebagaimana diatur dan diancam pidana pada pasal 114 ayat (1) Undang-Undang R.I No. 35 Tahun 2009 tentang Narkotika jo pasal 1 UndangUndang R.I No. 11 Tahun 2012 tentang Sistem Peradilan Pidana Anak.

b. Subsidair : Perbuatan terdakwa sebagaimana diatur dan diancam pidana pada pasal 127 ayat (1) huruf a UndangUndang R.I No. 35 Tahun 2009 tentang Narkotika jo pasal 1 Undang-Undang R.I No. 11 Tahun 2012 tentang Sistem Peradilan Pidana Anak.

\section{Analisa Putusan Hakim Pengadilan Negeri Tembilahan Nomor 28/Pid.Sus.A/2013/PN.Tbh}


a. Berdasarkan analisa hakim menyatakan terdakwa anak HENGKY ADI SAPUTRA BIN HERMAN tidak terbukti secara sah dan meyakinkan bersalah melakukan tindak pidana sebagaimana yang termuat dalam dakwaan primair yang didakwakan oleh Jaksa Penuntut Umum ;

b. Serta hakim berpendapat untuk Membebaskan terdakwa anak HENGKY ADI SAPUTRA BIN HERMAN dari dakwaan primair yang didakwakan oleh Jaksa Penuntut Umum ;

c. Serta hakim Menyatakan Terdakwa anak HENGKY ADI SAPUTRA BIN HERMAN, telah terbukti secara sah dan meyakinkan bersalah melakukan tindak pidana "Menyalahgunakan Narkotika Golongan I bagi diri sendiri";

d. Hakim Menjatuhkan pidana terhadap terdakwa anak tersebut diatas dengan pidana penjara selama : 1 (satu) tahun.

e. Hakim Memerintahkan masa penangkapan dan masa penahanan yang telah dijalani terdakwa anak dikurangkan seluruhnya dari pidana yang dijatuhkan;

\section{Alasan Pertimbangan Hakim Pengadilan Tinggi Pekanbaru ${ }^{32}$}

Sehubungan dengan hasil putusan hakim pengadilan negeri tembilahan bahwa atas putusan tersebut Jaksa Penuntut Umum telah mengajukan permintaan banding, pada tanggal 18 Maret 2013 sebagaimana Akta Permintaan banding Nomor : 02/Akta.Pid.Sus.A/2013/PN.Tbh.permintaan banding tersebut telah diberitahukan kepada

\footnotetext{
${ }^{32}$ Ibid
}

Penasehat Hukum Terdakwa pada tanggal 9 April 2013 ;

Serta Jaksa Penuntut Umum telah mengajukan memori banding tertanggal 28 Maret 2013, yang telah diterima di Kepaniteraan Pengadilan Negeri Tembilahan pada tanggal 1 April 2013, memori banding tersebut telah diberitahukan kepada Pesehat Hukum Terdakwa pada tanggal 9 April 2013 ;

Dan hakim menimbang bahwa sebelum berkas perkara dikirim ke Pengadilan Tinggi, kepada Terdakwa dan Jaksa Penuntut Umum telah diberi kesempatan untuk mempelajari berkas perkara sesuai dengan Surat pemberitahuan untuk mempelajari berkas perkara tanggal 8 April 2013 Nomor : W4-U5/461/HN.01.10/III/2013 ;

Hakim pun Menimbang bahwa oleh karena permintaan banding Jaksa Penuntut Umum telah diajukan dalam tenggang waktu dan telah dilakukan menurut cara-cara yang ditentukan oleh Undang-Undang, maka permintaan banding tersebut secara formal dapat diterima ;

Pertimbangan hakim bahwa memori banding Jaksa Penuntut Umum pada pokoknya sebagai berikut : Putusan hakim tingkat Pertama halaman 18 : "terdakwa Hengky Adi Saputra Bin Herman mengetahui jika yang diterangkan dan ditandatanganinya dalam berkas pemeriksaan adalah keterangannya tentang perbuatan bahwa ia membeli, menjual atau menggunakan daun ganja kering “,

Fakta ini dihubungkan dengan pertimbangan hakim terhadap unsur tanpa hak dan melawan hukum menawar untuk menjual, menjual, membeli, menjadi perantara dalam jual beli, menukar, menyerahkan atau menerima, sebagaimana dalam pertimbangan putusan halaman $21 \mathrm{~s} / \mathrm{d} \quad 22$, fakta 
persidangan ini oleh hakim tidak dipertimbangkan sehingga unsur ini tidak terpenuhi, selanjutnya membebaskan terdakwa dari dakwaan primeir. Oleh karena itu, mohon agar hakim banding mempertimbangkan fakta persidangan tersebut berdasarkan Pasal 240 (1) KUHAP, dan selanjutnya Pengadilan Tinggi menerima permohonan banding Jaksa Penuntut Umum dengan memutus tetap sebagaimana tuntutan semula ;

Lalu hakim pun menimbang bahwa setelah mempelajari dengan seksama berkas perkara dan putusan Pengadilan Negeri Tembilahan No. 28/Pid.Sus.A/2013/PN.Tbh, tanggal 14 maret 2013 serta memori banding Jaksa Penuntut Umum, Pengadilan Tinggi tidak sependapat dengan hakim tingkat pertama dengan pertimbangan sebagai berikut dibawah ;

Bahwa terdakwa diajukan ke persidangan dengan dakwaan subsidair sebagai berikut :

a. Primair : Setiap orang tanpa hak atau melawan hukum menawarkan untuk dijual, menjual, Membeli, menerima, menjadi perantara dalam jual beli, menukar, atau menyerahkan narkotika golongan I ; diatur dan diancam pidana dalam Pasal 114 (1) UU RI No. 35 Tahun 2009 tentang Narkotika Jo Pasal 1 UU RI No. 3 Tahun 1997 tentang Pengadilan Anak.

b. Subsidair : Setiap penyalah guna narkotika golongan I berupa ganja (cannabinoid) bagi diri sendiri ; diatur dan diancam pidana dalam Pasal 127 (1) huruf a UU RI No. 35 Tahun 2009 tentang Narkotika Jo Pasal 1 UU RI No. 3 Tahun 1997 tentang pengadilan Anak ;
Bahwa unsur-unsur dakwaan primair tersebut adalah

1. Setiap orang (anak) ;

2. tanpa hak atau melawan hukum menawarkan untuk dijual, menjual, membeli, menerima,menjadi perantara dalam jual beli, menukar, atau menyerahkan ;

3. narkotika golongan I ;

$\begin{array}{ll}\text { 5. Putusan Pengadilan } & \text { Tinggi } \\ \text { Pekanbaru } & \text { Nomor } \\ \text { 68/PID.SUS/2013/PTR } & \\ \text { Membatalkan } & \text { putusan }\end{array}$
Pengadilan Negeri Tembilahan No. : 28 / Pid.Sus/A/2013/ PN.TBH, Tanggal 14 Maret 2013 an. Terdakwa HENGKY ADI SAPUTRA Bin HERMAN yang dimintakan banding tersebut ;

MENGADILI SENDIRI :

1. Menyatakan bahwa terdakwa HENGKY ADI SAPUTRA Bin HERMAN telah terbukti secara sah dan meyakinkan bersalah melakukan tindak pidana "tanpa hak/melawan hukum membeli dan menjual narkotika golongan I" ;

2. Menjatuhkan pidana terhadap terdakwa tersebut dengan pidana penjara selama 2 (dua) tahun 6 (enam) bulan dan pidana denda sebesar Rp. 500.000.000,-(lima ratus juta rupiah) ; apabila denda termaksud tidak dapat dibayar, maka diganti dengan wajib latihan kerja selama 30 (tiga puluh) hari;

3. Menetapkan bahwa masa selama terdakwa ditangkap dan ditahan dikurangkan seluruhnya dari pidana yang dijatuhkan ;

4. Memerintahkan agar terdakwa tetap ditahan ;

\section{Kesimpulan}

\footnotetext{
${ }^{33}$ Ibid
} 
IBLAM LAW REVIEW

SEKOLAH TINGGI ILMU HUKUM IBLAM

Vol 1 No 1 2021, Hal 96-114

1. Penegakan hukum terhadap pelaku tindak pidana anak di bawah umur yang menyalahgunakan narkotika merujuk kepada Pasal 133 Undang-Undang Nomor 35 tahun 2009 tentang Narkotika yang menjelaskan sebagai berikut : "Setiap orang yang menyuruh, memberi atau menjanjikan sesuatu, memberikan kesempatan, menganjurkan, memberikan kemudahan, memaksa dengan ancaman, memaksa dengan kekerasan, melakukan tipu muslihat, atau membujuk anak yang belum cukup umur. Pasal tersebut di atas, hanya dikenakan terhadap orang yang memanfaatkan anak yang belum dewasa saja, sedangkan anak yang bersangkutan tetap dapat dipidana berdasarkan ketentuan undang-undang narkotika sesuai dengan perbuatannya. Namun, dikarenakan anak di bawah umur maka berlakulah ketentuan undang-undang peradilan anak, yang terdapat pada Undang-Undang Nomor 11 tahun 2012 tentang Sistem Peradilan Pidana Anak.

2. Penerapan hukum materiil terhadap anak sebagai penyalahguna narkotika sebagaimana dalam Putusan Pengadilan Nomor: 68/PID.SUS/2013/PTR, ternyata ada perbedaan tafsir dan perbedaan pertimbangan sehingga terjadi perbedaan pemberian sanksi pidana terhadap terdakwa. Hakim Pengadilan Negeri menjatuhkan pidana penjara selama 1 (satu) tahun, sedangkan hakim Pengadilan Tinggi menjatuhkan sanksi lebih berat yaitu 2 (dua) tahun 6 (enam) bulan penjara., yang akhirnya harus dijalani, karena perkara ini hanya sampai di tingkat banding di pengadilan Tinggi.

\section{E. Daftar Pustaka}

\section{Buku}

A Hamid S Attamimi, Perkembangan Pembentukan Undang-Undang Di Indonesia, Jakarta; Konstitusi Press, 2014

Arif Gosita, Permasalahan Perlindungan Anak, Akademi Presindo, Jakarta. 2009

A. R. Sujono, dan Bony Daniel, Komentar\&Pembahasan Undang Undang Nomor 35 Tahun 2009 tentang Narkotika, Jakarta, Sinar Grafika, 2013

Atmasasmita, Romli, Tindak Pidana Narkotika Transnasional Dalam Sistem Hukum Pidana Indonesia, Bandung: PT. Citra Aditya Bakti. 2007

Bambang Mudjianto, Petunjuk Praktis Metode Penelitian Kualitatif,

Tiarana Lokus, yogyakarta, 2014, Barda Nawawi Arif, Sari Kuliah Hukum Pidana II. Fakultas Hukum Undip.2004

Dani Krisnawati, dkk., Bunga Rampai Hukum Pidana Khusus, Jakarta, Pena Pundi Aksara, 2006

Hadiman, Perlakukanlah Barang Haram Ecstasy, Narkotika Dll Seperti barang Haram Lainnya, Jakarta: Yayasan Al Washilah. 2006

Hamzah, Andi, dan Surachman, Kejahatan Narkotika Dan 
Psikotropika, Jakarta: Sinar

Grafika. 2004

Hamzah, Andi, Pengantar Hukum Acara

Pidana Indonesia, Jakarta : Ghalia Indonesia. 2005

Harun M.Husen, Kejahatan dan

Penegakan Hukum Di Indonesia,

Rineka Cipta, Jakarta, 2000

Huda, Chairul, Dari Tiada Pidana Tanpa

Kesalahan Menuju Kepada Tiada

Pertanggungjawaban Pidana

Tanpa Kesalahan, Jakarta: Prenada

Media. 2006

Koesnadi Hardjasoemantri, Hukum Tata

Lingkungan, Ed. Ketujuh, Cet, 14,

Gadjah Madah University Press,

Yogyakarta. 2009

Lisa, Juliana, dan Nengah Sutrisna,

Narkoba, Psikotropika Dan

Gangguan Jiwa, Yogyakarta: Nuha

Medika. 2013

Mahmud Marzuki, Penelitian Hukum,

Kencana, Jakarta, 2010

Maidin Gultom, Perlindungan Hukum

Terhadap Anak, Bandung, Refika

Aditama, 2008

Ma'roef, Ridho, Narkotika Bahaya Dan

Penanggulanganya, Jakarta :

Karisma Indonesia. 2006

Makaro, Taufik, Suhasril, dan Moh.

Zakky, Tindak Pidana Narkotika,

Jakarta: Ghalia Indonesia. 2005

Marzuki, Peter Mahfud, Penulisan

Hukum, Jakarta: Kencana Media

Group. 2006

Muhammad Yamin, Tindak Pidana

Khusus, Bandung: Pustaka Setia, 2012
Moeljatno, Kitab Undang-undang Hukum Pidana, Jakarta: Bumi Aksara. 2009

Nyoman Serikat Putra Jaya, Kapita Selekta Hukum Pidana, Badan PenerbitUniversitas Diponegoro, Semarang, 2001

Prodjodikoro, Wirjono. Tindak Tindak

Pidana Tertentu Di Indonesia.

Refika Aditama. Bandung, 2008

Rena, Yulian, Victimologi, Yogyakarta:

Graha Ilmu. 2009

Ronny Hanitijo, Metodologi Penelitian

Hukum, Jakarta : Ghalia Indonesia, 2000

Saleh, Wantjik K, Tindak Pidana

Korupsi dan Suap, Jakarta,

Paramestika, 1996

Satjipto Rahardjo, Penegakan Hukum suatu tinjauan sosiologis, Genta

Publishing, Yogyakarta. 2009

Sudikno Mertokusumo, Bunga Rampai Ilmu Hukum, Yogyakarta : Liberty, 2000

Supramono, Gatot, Hukum Narkoba Indonesia, Jakarta: Djambatan. 2009 Hukum Acara

Pengadilan Anak, Jakarta:

Djambatan. 2012

Soedjono Dirjosisworo, Hukum

Narkotika Indonesia, Bandung,

Citra Aditya Bhakti, 2005

Soedjono, Narkotika Dan Remaja, Bandung: Alumni. 2003

Soerjono Soekanto, Faktor-faktor Yang

Mempengaruhi Penegakan Hukum, UI Pres, Jakarta, 2001,

Hukum, UI Press, Jakarta, 2010 
Soekanto Soerjono dan Sri Mamudji, Penelitian Hukum Normatif Suatu Tinjauan Singkat, PT RajaGrafindo Persada, 1995

Soerjowinoto, Petrus, dan Kawan-kawan, Metode Penulisan Karya Hukum, Semarang: Fakultas Hukum Unika Sogijapranata. 2014

Soemitro, Ronni Hanitijo, Metodologi Penelitian Hukum, Jakarta: Ghalia Indonesia. 2005

S.R Sianturi, Asas-asas Hukum Pidana

Di Indonesia dan Penerapannya, Cet. 4, Jakarta, Percetakan BPK Gunung Mulia, 2006

Sudarto, Hukum dan Hukum Pidana, Bandung: Alumni. 2001

Waluyo, Bambang, Penelitian Hukum Dalam Praktek, Jakarta: Sinar Grafika. 2001

\section{Peraturan Perundang-Undangan :}

Undang-Undang Nomor 8 tahun 1981 tentang Hukum Acara Pidana.

Undang-Undang Nomor 35 tahun 2009 tentang Narkotika.

Undang-Undang Nomor 5 tahun 1997 tentang Psikotropika.

Undang-Undang Nomor 25 tahun 2011 tentang Pelaksanaan Wajib Lapor Pecandu Narkotika.

Undang-Undang Nomor 23 tahun 2010 tentang Badan Narkotika Nasional.

Peraturan Pemerintah Nomor 25 Tahun 2011 tentang Pelaksanaan Wajib Lapor bagi Pecandu Narkotika.

Peraturan Kepala Badan Narkotika Nasional Nomor 11 tahun 2014, tentang Tata Cara Penanganan Tersangka dan/atau Terdakwa
Pecandu Narkotika dan Korban Penyalahgunaan Narkotika ke dalam Lembaga Rehabilitasi.

Surat Edaran Mahkamah Agung Nomor 04 tahun 2010, tentang Penempatan Penyalahgunaan, Korban Penyalahgunaan dan Pecandu Narkotika Ke dalam Lembaga Rehabilitasi Medis dan Lembaga Rehabilitasi Sosial.

Peraturan Bersama Ketua Mahkamah Agung, Menteri Hukum dan Hak Asasi Manusia, Menteri Kesehatan, Menteri sosial, Jaksa Agung, Kepala Kepolisian, Kepala Badan Narkotika Nasional, Nomor: 01/PB/MA/III/2014, Nomor: 03 tahun 2014, Nomor: 11 tahun 2014, Nomor: 03 tahun 2014, Nomor: PER-005/A/JA/03/2014, Nomor: 01 tahun 2014, Nomor: PERBER/01/III/2014/BNN, tentang Penanganan Pecandu dan Korban Penyalahgunaan Narkotika Ke dalam Lembaga Rehabilitasi. Peraturan Menteri Kesehatan, Nomor 13 tahun 2014, tentang Perubahan Penggolongan Narkotika. 